\title{
ANALISA PENGARUH PERUBAHAN FED FUND RATE, INDEX HARGA SAHAM GABUNGAN DAN INDEKS LQ45 TERHADAP NILAI TUKAR DOLLAR AMERIKA - RUPIAH
}

\author{
Ricky Suanto \\ Program Studi Magister Manajemen Universitas Tarumanagara \\ ricx288@yahoo.com \\ Yanuar \\ Program Studi Magister Manajemen Universitas Tarumanagara \\ Masuk : 15-11-2019, revisi : 28-11-2019 diterima untuk diterbitkan : 29-11-2019
}

\begin{abstract}
The economy in Indonesia is experiencing a decline which can be seen from the decline in the Composite Stock Price Index in Indonesia. The decline in the value of the Composite Stock Price Index and Liquid 45 Index (LQ45) affected the rupiah exchange rate against US dollars that have passed the psychological level limit of Rp. 15,000 per 1 USD. The weakening of the rupiah and the index value of the stock was triggered by an increase in interest rates set by the Federal which increase Fed Fund Rate to 2.25\% in September 2018.

This study aims to explain whether it is true that the announcement of changes in the central bank's fed funds rate in the United States can be related and influence the Stock Price Index and Exchange Rates in other countries, especially in Indonesia.

After collecting and processing data with Path Analysis, the results show that the impact in average of the fed fund rate to the average return LQ45 index has the strongest effect compared to other variables, then the strongest effect value is produced by the effect of average return Composite Stock Price Index to the average return of the US Dollar - Rupiah which is negative 0.76. After going through the mediation process, the indirect effect that occurs between the average fed fund rate on the average return of the US Dollar - Rupiah is positive 0.451, which significantly stagnant and changes the direction of the effect compared to its direct effect of negative 0.46 .
\end{abstract}

Abstrak : Perekonomian di Indonesia mengalami penurunan yang dapat dilihat dari penurunan Indeks Harga Saham Gabungan di Indonesia. Penurunan nilai Indeks Harga Saham Gabungan dan Indeks Liquid 45 (LQ45) memengaruhi nilai tukar rupiah terhadap dolar AS yang telah melewati batas level psikologis Rp. 15.000 per 1 USD. Pelemahan rupiah dan nilai indeks saham dipicu oleh kenaikan suku bunga yang ditetapkan oleh Federal yang meningkatkan Suku Bunga Fed Fund menjadi 2,25\% pada September 2018.

Penelitian ini bertujuan untuk menjelaskan apakah benar bahwa pengumuman perubahan tingkat suku bunga The Fed di Amerika Serikat dapat dikaitkan dan mempengaruhi Indeks Harga Saham dan Nilai Tukar di negara lain, terutama di Indonesia.

Setelah mengumpulkan dan mengolah data dengan metode Path Analysis, hasil analisa menunjukkan bahwa pengaruh average suku bunga The Fed terhadap average return indeks LQ45 memiliki persentase pengaruh yang paling kuat dibandingkan dengan variabel lain, selanjutnya nilai pengaruh terkuat dihasilkan oleh pengaruh average return Indeks Harga Saham Gabungan terhadap average return Dolar AS - Rupiah yang bernilai negatif 0,76. Setelah melalui proses mediasi, pengaruh tidak langsung yang terjadi antara average fed fund rate terhadap average return Dolar AS - Rupiah adalah positif 0,451, yang stagnan dan hanya mengubah arah efek dibandingkan dengan efek langsung negatifnya yang bernilai 0,46 . 
Keywords : fed fund rate, foreign exchange, stock index, Jakarta Composite Index, Index LQ45, US Dollar, Rupiah

\section{PENDAHULUAN}

Memasuki akhir kuartal ke-3 (tiga) tahun 2018 Indeks Harga Saham Gabungan (IHSG) terkoreksi kurang lebih 500 poin dari awal tahun 2018. Penurunan nilai Indeks Harga Saham Gabungan (IHSG) dan Indeks Liquid 45 (LQ45) berpengaruh kepada nilai tukar rupiah terhadap dollar amerika yang sudah melewati batas level psikologis yaitu Rp 15.000 (Lima Belas Ribu Rupiah) per 1 USD (Satu Dollar Amerika). Pelemahan nilai rupiah dan nilai indeks saham tersebut dipicu oleh kenaikan bunga yang ditetapkan bank sentral The Federal yang pada bulan September 2018 meningkat sebesar 2.0\% dari titik terendahnya di tahun 2008 yaitu $0.25 \%$.

Berdasarkan informasi di atas, peneliti tertarik untuk meneliti pengaruh dan hubungan antara kenaikan dan penurunan bunga bank sentral The Federal dengan nilai tukar Rupiah dan Dollar Amerika Serikat dengan Indeks Harga Saham Gabungan (IHSG) dab Indeks Liquid 45 (LQ45) sebagai mediasi. Sehingga dapat diketahui erat, dan arah pengaruh serta signifikan atau tidaknya hubungan antar setiap variabel baik secara langsung, maupun tidak langsung.

\section{TINJAUAN PUSTAKA}

Saham merupakan suatu instrumen investasi yang diperjualbelikan di pasar modal. Menurut Hartono, Jogiyanto (2015) Saham merupakan hak kepemilikan sebuah perusahaan. Apabila perusahaan tersebut hanya mengeluarkan 1 (satu) kelas saham saja, maka saham ini disebut saham biasa (common stock) sedangkan ada kelas lain saham yang disebut saham preferen (preferred stock). Saham preferen (preferred stock) memiliki hak-hak prioritas yakni mendapatkan deviden dan kemudahan likuidasi, akan tetapi saham preferen (preferred stock) tidak memiliki hak veto untuk mengatur perusahaan seperti yang didapatkan pada kepemilikan saham biasa (common stock).

Suatu indikator dibentuk untuk mengetahui pergerakan keseluruhan saham, sehingga terbentuklah indeks harga saham gabungan yang menurut Darmadji, Tjiptono dan Hendry M Fakhruddin (2011), indeks harga saham adalah indikator yang menunjukan pergerakan harga saham. Pergerakan indeks menggambarkan bagaimana kondisi pasar pada suatu saat, apakah pasar sedang aktif atau lesu. Namun, Indeks harga saham gabungan (IHSG) yang mencangkup semua saham yang tercatat dianggap kurang tepat digunakan sebagai indikator kegiatan pasar modal, oleh karena itu dikenalkan alternatif indeks lain yaitu Indeks Liquid 45 (LQ45) yang menurut Hartono, Jogiyanto (2015) merupakan Indeks ini dibentuk dari 45 (empat puluh lima) saham-saham yang paling aktif diperdagangkan.

Indikator ekonomi tidak hanya dibelihat dari pegerakan saham saja, karena masingmasing negara di seluruh dunia memiliki jenis mata uang masing-masing seperti Indonesia dengan Rupiah dan Amerika Serikat dengan Dollar. Menurut Mishkin, Frederic S. dan Stanley G. Eakins (2015) nilai tukar merupakan nilai harga dari satu mata uang terhadap mata uang lain.

Institusi keuangan yang paling penting adalah bank sentral. Menurut Mishkin, Frederic S. dan Stanley G. Eakins (2015) bank sentral adalah institusi pemerintah yang memiliki tanggung jawab untuk mengatur kebijakan moneter termasuk nilai suku bunga dan jumlah uang beredar sehingga bank sentral dapat mempengaruhi inflasi, siklus bisnis dan banyak hal-hal lain yang berhubunagn dengan aspek keuangan di suatu negara. Di Amerika Serikat bank sentral disebut Federal Reserve System atau biasa dipanggil The Fed. 


\section{METODOLOGI PENELITIAN}

Tipe dari penelitian ini adalah penelitian penjelasan (explanatory research) yang merupakan penelitian yang bertujuan untuk menjelaskan hubungan-hubungan antara satu variabel dengan variabel lain melalui pengajuan hipotesis.

Periode data yang diambil dalam penelitian ini adalah data harian dari tahun 2008 hingga 2018.

Data yang digunakan dalam penelitian ini merupakan data sakunder yang merupakan data-data yang diperoleh dari penelitian sebelumnya ataupun lembaga-lembaga yang memang menyediakan data tersebut.

Data-data variabel independen berupa tingkat bunga bank sentral fed fund rate, variabel mediasi berupa Indeks Harga Saham Gabungan (IHSG) dan Indeks Liquid 45 (LQ45) dan variabel dependen berupa, Nilai Tukar USD-IDR, didapatkan dari website Yahoo Finance (www.yahoo.com/finance), Investing (www.investing.com), Situs resmi federal reserve system (www.federalreserve.gov) dan Situs resmi Bursa Efek Indonesia (www.idx.co.id).

Selanjutnya data-data yang sudah diperoleh akan diproses dan dianalisa menggunakan metode path analysis sehingga dapat menghasilkan hasil pengolahan data yang akurat. Menurut Sarjono, Haryadi dan Winda Julianita (2014) analisa jalur (path analysis) digunakan untuk mengetahui pengaruh langsung maupun tidak langsung seperangkat variabel bebas terhadap variabel terikat. Data-data tersebut kemudian akan diolah menggunakan program berupa Microsoft Excel, dan SPPS AMOS.

\section{HASIL DAN KESIMPULAN}

Setelah data-data diolah dan dikalkulasi, didapatkan hasil berupa 4 (empat) tabel yang menggambarkan hubungan, pengaruh langsung dan pengaruh setelah dilakukan mediasi, sebagai berikut :

\section{Regression Weights}

\begin{tabular}{|c|c|c|c|c|c|c|c|}
\hline & & & Estimate & S.E. & C.R. & $\mathrm{P}$ & Label \\
\hline Ret_LQ45 & $<--$ & Avg_fed & -1.856 & .673 & -2.756 & .006 & \\
\hline Ret_IHSG & $<---$ & Avg_fed & -1.607 & .599 & -2.685 & .007 & \\
\hline Ret_USDIDR & $<--$ & Ret_IHSG & -.388 & .029 & -13.403 & *** & \\
\hline Ret_USDIDR & $<--$ & Ret_LQ45 & .093 & .026 & 3.614 & $* * *$ & \\
\hline Ret_USDIDR & $<--$ & Avg_fed & -.459 & .210 & -2.183 & .029 & \\
\hline
\end{tabular}

Standardized Regression Weights

\begin{tabular}{|c|c|c|}
\hline & & Estimate \\
\hline Ret_LQ45 & <--- Avg_fed & -.233 \\
\hline Ret_IHSG & <--- Avg_fed & -.228 \\
\hline Ret_USDIDR & $<---\quad$ Ret_IHSG & -.764 \\
\hline Ret_USDIDR & $<---$ Ret_LQ45 & .206 \\
\hline Ret_USDIDR & <--- Avg_fed & -.128 \\
\hline
\end{tabular}

Indirect Effect

\begin{tabular}{|l|rrr|}
\hline & Avg_fed & Ret_IHSG & Ret_LQ45 \\
\hline Ret_IHSG & .000 & .000 & .000 \\
Ret_LQ45 & .000 & .000 & .000 \\
Ret_USDIDR & .451 & .000 & .000 \\
\hline
\end{tabular}




\begin{tabular}{|l|rrr|}
\multicolumn{4}{c}{ Standardized Indirect Effect } \\
\begin{tabular}{|l|rrr|}
\hline & Avg_fed & Ret_IHSG & Ret_LQ45 \\
\hline Ret_IHSG & .000 & .000 & .000 \\
Ret_LQ45 & .000 & .000 & .000 \\
Ret_USDIDR & .126 & .000 & .000 \\
\hline
\end{tabular}
\end{tabular}

Berdasarkan hasil pembahasan penelitian yang berjudul "Analisa Pengaruh Perubahan Fed Fund Rate, Index Harga Saham Gabungan Dan Indeks LQ45 Terhadap Nilai Tukar Dollar Amerika - Rupiah" maka dapat ditarik kesimpulan sebagai berikut :

1. Seluruh variabel bebas dan terikat yang diteliti dalam penelitian ini memiliki hubungan yang signifikan, sehingga semua variabel saling berhubungan erat satu dengan lainnya.

2. Besar pengaruh langsung antara rata-rata fed fund rate dengan average return Dollar Amerika - Rupiah bernilai negatif 0.13 sehingga arah hubungannya berbanding terbalik dan merupakan pengaruh antar variabel yang paling lemah dibandingkan dengan pengaruh antara variabel lainnya.

3. Pengaruh yang terkuat dihasilkan oleh pengaruh average return Indeks Harga Saham Gabungan terhadap average return Dollar Amerika - Rupiah yang bernilai negatif 0.76 .

4. Kontribusi pengaruh langsung antara rata-rata fed fund rate terhadap average return Dollar Amerika - Rupiah bernilai negative 0.46 yang dapat diartikan bahwa ketika ratarata fed fund rate meningkat sebesar 1\%, maka average return Dollar Amerika - Rupiah akan menurun sebesar $0.46 \%$ dan sebaliknya apabila rata-rata fed fund rate menurun sebesar 1\%, maka average return Dollar Amerika - Rupiah akan meningkat sebesar $0.46 \%$.

5. Setelah melalui proses mediasi, besarnya pengaruh yang terjadi antara rata-rata fed fund rate dengan average return Dollar Amerika - Rupiah bernilai positif 0.126. Sehingga dapat diartikan bahwa arah pengaruhnya menjadi berbanding lurus dan dengan besaran nilai yang kurang lebih sama dengan pengaruh langsungnya.

6. Setelah melalui proses mediasi, kontribusi pengaruh tidak langsung yang terjadi antara rata-rata fed fund rate terhadap average return Dollar Amerika - Rupiah bernilai positif 0.451 sehingga arah pengaruhnya berubah menjadi berbanding lurus dan dengan kekuatan yang hampir sama dibandingkan dengan pengaruh langsungnya yang sebesar negatif 0.46 . Sehingga, ketika rata-rata fed fund rate meningkat sebesar $1 \%$, maka average return Dollar Amerika - Rupiah akan meningkat sebesar $0.451 \%$ dan sebaliknya apabila rata-rata fed fund rate menurun sebesar 1\%, maka average return Dollar Amerika - Rupiah akan menurun sebesar $0.451 \%$ setelah dimediasi oleh variabel average return Indeks Harga Saham Gabungan dan Indeks LQ45.

\section{DAFTAR PUSTAKA}

Arfaoui, M., \& Ben Rejeb, A. (2017). Oil, gold, US dollar and stock market interdependencies: a global analytical insight. European Journal of Management and Business Economics, 26(3), 278-293.

Bernanke, B. S., \& Kuttner, K. N. (2016). American Finance Association What Explains the Stock Market's Reaction to Federal Reserve Policy? The Journal of Finance, 60(3), 1221-1257.

Blanchard, Olivier dan Johnson, David. R. (2013). Makroekonomi: Edisi Keenam. Jakarta: Penerbit Erlangga.

Chow, Hwee Kwan, dan Yoonbai Kim. (2004). The Empirical Relationship Between Exchange Rates and Interest Rates in Post-Crisis Asia. School of Economics and Social Sciences, Singapore Management University

Darmaji, T \& Fakhruddin, H. (2011). Pasar Modal di Indonesia: Edisi 3. Jakarta: Salemba Empat. 
Ekanayake, E.M, Robin Rance, dan Mihalis Halkides. (2008). Effects Of Federal Funds Target Rate Changes On Stock Prices. The International Journal of Business and Finance Research Vol 2-1 2008.

Gom, H. G. O. M. P. (2013). Analisis Pengaruh the Fed Rate, Indeks Dow Jones Dan Indeks Nikkei225 Terhadap Indeks Harga Saham Gabungan ( Ihsg ) Di Bursa Efek Indonesia ( Bei ) Periode 2008-2013. Jurnal Ekonomi Dan Keuangan, 1(8), 26-38.

Handiani, S. (2014). Pengaruh Harga Emas Dunia, Harga Minyak Dunia dan Nilai Tukar Dolar Amerika/Rupiah Terhadap Indeks Harga Saham Gabungan Pada Periode 2008-2013. EJournal Graduate Unpar, 1(1), 1-13.

Hartono, Jogiyanto. (2008). Teori Portofolio dan Analisis Investasi : Edisi Kesebelas. Yogyakarta: BPFE-Yogyakarta.

Kearns, Jonathan dan Phil Manners. (2006). The Impact of Monetary Policy on the Exchange Rate: A Study Using Intraday Data. International Journal of Central Banking

Lorie, James H., Peter Dodd, dan Mary Hamilton Kimpton. (1985). The Stock Market Theories and Evidance. Illinois: Jones-Irwin.

Mishkin, Frederic S. dan Eakins, Stanley G. (2008). Financial Markets and Institutions: Eighth Edition. United States: Pearson.

Maryatmo, R. (2008). Pengaruh Jangka Pendek dan Jangka Panjang Perubahan Suku Bunga dan Kurs Rupiah Terhadap Harga Saham : Studi Empiris di Indonesia (2000:1 - 2010:4). Munich Personal RePEc Archive, (66085).

Mayzan, M. B. (2018). Pengaruh Kurs Rupiah , Bi Rate , Net Foreign Fund Dan Indeks Dow Jones Terhadap Indeks Harga Saham Gabungan ( Studi Pada Periode Pemberlakuan Quantitative Easing Federal Reserve ). Jurnal Administrasi Bisnis (JAB), 56(1).

Park, Donghyun, Shu Tian, Irfan Qureshi, dan Mai Lin Villaruel. (2019). Impact of Monetary Policy Uncertainty on Asian Exchange Rates. ADB BRIEFS No 111, July 2019.

Rose, Peter S. (2003). Money and Capital Market: Eighth Edition. United States: McGraw Hill.

Rigobon, R., \& Sack, B. (2004). The impact of monetary policy on asset prices. Journal of Monetary Economics, 51(8), 1553-1575.

Risman, A., Salim, U., Sumiati, S., \& Indrawati, N. K. (2017). Commodity prices, exchange rates and investment on firm's value mediated by business risk: A case from Indonesian stock exchange. European Research Studies Journal, 20(3), 511-524.

Setyastuti, R. (2008). Keterkaitan Antara Nilai Tukar, Tingkat Suku Bunga dan Indeks Harga Saham di Indonesia. Jurnal Ekonomi Dan Studi Pembangunan, 16(April), 14-25.

Syarif, M. M., \& Asandimitra, N. (2008). Pengaruh Indikator Makro Ekonomi Dan Faktor Global Terhadap Indeks Harga Saham Gabungan (IHSG). Jurnal Studi Manajemen, 9(2).

Sarjono, Haryadi dan Julianita, Winda. (2014). SPSS VS LISREL: Sebuah Pengantar; Aplikasi Untuk Riset. Jakarta: Salemba Empat.

Tan, Kok-Hui, Keshab Shrestha. (2005). The Impact of Fed Fund Rate Target Changes on the Asian Stock Market - Empirical Evidence. Centre For Research in Financial Services Working Paper No. 96-05

Thaddeus, O. (2014). Exchange Rate, Inflation and Interest Rates Relationships: AnAutoregressive Distributed Lag Analysis Ebiringa, Oforegbunam Thaddeus 1 and Anyaogu, Nnneka, B. 2, 2(2), 263-279.

Widoatmodjo, Sawidji. (2009). Pasar Modal Indonesia: Pengantar dan Studi Kasus. Bogor Selatan: Penerbit Ghalia Indonesia.

Widoatmodjo, Sawidji. (2008). Pengetahuan Pasar Modal: Untuk Konteks Indonesia. Jakarta: Elex Media Komputindo.

Wijayaningsih, R., Rahayu, S. M., \& Saifi, M. (2016). Pengaruh BI Rate, FED Rate dan Kurs Rupiah Terhadap Indeks Harga Saham Gabungan (IHSG) (Studi pada Bursa Efek Indonesia Periode 2008-2008). Jurnal Administrasi Bisnis, Vol. 33(No. 2), 69-75. 